удК $347.77 / 78$

DOI https://doi.org/10.32837/apdp.v0i88.3053

А. В. Длитрук

\title{
СВОБОДА ТВОРЧОСТІ: ПОНЯТТЯ, ОЗНАКИ, СУТНІСНІ ВИМІРИ
}

Постановка проблеми. Підтримання інновацій неминуче приводить до прогресу в суспільстві, сфера інтелектуальної власності стрімко розвивається та з'являються нові об'єкти права інтелектуальної власності, які потребують визнання та правової охорони. У багатьох конституціях сучасних держав ідеться про інтелектуальну власність, пов'язану із творчою працею, що знаходить своє відображення в певній сукупності відповідних прав і обов'язків. Ця обставина підкреслює значення свободи творчості й інтелектуальної власності в сучасному світі, актуальність дослідження теми творчості, оскільки творчість не є сталим явищем, вона стрімко розвивається і на своєму шляху стикається із суперечностями, які потребують вирішення. Основою створення будь-якого об'єкта права інтелектуальної власності є культурні надбання попередніх поколінь. Але не менш важливі й результати інтелектуальної творчої діяльності, які створюються сьогодні і будуть створюватися в майбутньому. Кількість та різноманітність результатів творчості роблять очевидною потребу вдосконалення законодавства у сферах їx використання.

Аналіз останніх досліджень і публікацій. Питання свободи творчості досліджено у працях М. Бердяєва, Д. Богоявленської, В. Дружиніна, Ю. Гільбуха, І. Калошиної, Н. Лейтеса, Б. Теплова, А. Холодної, Ф. Баррона, М. Воллаха, Д. Гілфорда, С. Медніка, Р. Стенберга, Е. Торренса, Л. Виготського, О. Залужного, Г. Костюка, О. Леонтьєва, К. Платонова й інших.

Виділяють чотири основні підходи до розгляду творчості. Творчість у галузі розвитку творчих умінь як потреба у професійному зростанні вивчалась такими науковцями, як Д. Богоявлинська, Ю. Цагареллі, В. Андреєв, Б. Теплов. Творчість як процес, а саме спостереження механізму творчого акту, досліджували М. Бердяєв, Д. Гілфорд, Н. Гузій, М. Поташник, В. Шубинськиий. Творчість як кінцевий продукт розглядають як ознаку новизни й унікальності С. Сисоєва, Г. Падалка. Творчість як діяльність розглядали з позиції розв'язання оригінальних завдань Л. Арчажнікова, З. Левчук, А. Ковальов та інші.

Метою статті $€$ дослідження та соціально-правовий аналіз доктрини та положень законодавства щодо суті поняття свободи творчості, визначення ознак творчості та співвідношення свободи творчості з поняттям культури та суспільної моралі.

Виклад основного матеріалу дослідження. В Україні на конституційному рівні (ч. 1 ст. 41 Конституції) закріплені права володіння, користування і розпорядження результатами своєї інтелектуальної, творчої діяльності. Гарантується свобода літературної, художньої, наукової і технічної творчості та захист інтелектуальної власності, авторських прав, моральних і матеріальних інтересів, що виникають у зв'язку з різними видами інтелектуальної діяльності (ч. 1 ст. 54 Конституції). 
Основний закон України не випадково виділяє серед прав і законних інтересів у сфері інтелектуальної діяльності майнові та немайнові права. Адже у процесі літературної і художньої, наукової та технічної творчості виникають якісно нові знання, об'єкти матеріального та духовного світу, що мають свою вартість. У ст. 177 Цивільного кодексу (далі - ЦК) України визначено результати інтелектуальної, творчої діяльності, інформацію як об'єкти цивільних прав [10].

У ч. 1 ст. 418 ЦК України дано таке визначення: право інтелектуальної власності - це право особи на результати інтелектуальної, творчої діяльності або на інший об’єкт права інтелектуальної власності, визначений ЦК України й іншим законом. У ч. 2 ст. 418 ЦК України зазначено, що право інтелектуальної власності становлять особисті немайнові права інтелектуальної власності та (або) майнові права інтелектуальної власності, зміст яких щодо певних об’єктів права інтелектуальної власності визначається ЦК України й іншим законом.

Основою створення будь-якого об'єкта права інтелектуальної власності є культурні надбання попередніх поколінь. А. Коні писав, що творець як спадкоємець народного духу, який втілився в "розумових справах» попередніх поколінь, залишає прийдешнім поколінням свої здобутки як продукт цього духу, в іншій формі, вкладає в їх створення свої знання, спостережливість, уяву і фантазію, скуті воєдино і втілені в матеріальному носії. За це він отримує винагороду, пов'язану з авторським правом. Інтелектуальна спадщина суспільства надзвичайно важлива, оскільки вона є фундаментальною базою для подальшого культурного, наукового та технічного розвитку людини.

Термін «свобода» у «Великому тлумачному словнику сучасної української мови» пояснюється так:

- відсутність політичного й економічного гноблення, утиску та обмежень у суспільно-політичному житті якої-небудь верстви або всього суспільства; воля, державний суверенітет;

- перебування не під арештом, не ув'язненим, не в неволі і т. ін., без залежності від кого-небудь, можливість поводитися на свій розсуд;

- можливість діяти без перешкод і заборон у якій-небудь галузі. Свобода слова;

- філософська категорія - можливість вияву суб'єктом своєї волі в умовах усвідомлення законів розвитку природи і суспільства;

- легкість, відсутність утруднень у чому-небудь [7].

Гомер уважав, що вільною є та людина, яка не відчуває будь-якого зовнішнього тиску і діє за власним бажанням. Відомий французький державний діяч, історик та суспільствознавець Алексіс де Токвіль зазначав: «Хто шукає у свободі будь-що, крім самої свободи, створений для рабства». Польський філософ та історик Тадеуш Котарбіньський визначав: «Повна свобода можлива тільки як повна самотність», а Карл Маркс стверджував, що свобода настільки властива людині, що навіть її противники здійснюють її, борючись проти ії здійснення.

Згідно зі ст. 23 Конституції України, кожна людина має право на вільний розвиток своєї особистості, якщо водночас не порушуються права і свободи інших людей [1]. Закон окреслює загальні орієнтири для визначення правового балансу в суспільних відносинах. Ключ до розуміння співвідношення прав і свобод варто 
шукати у висуванні вимог тим чи іншим суб'єктом. Коли я постаю суб’єктом права, то отримую підставу висувати до інших належні вимоги. Це зумовлює відповідний до цього права обов'язок інших щодо мене, але вирішальним є те, що право передує обов'язкові й має більшу вагу, ніж він. Про це свідчить, наприклад, факт, що суб'єкт інколи може відмовитись від права, яке він має, або не претендувати на нього, і тоді, хоча право лишається тим самим, відповідати цьому обов'язку не може. Саме у висуванні вимог може полягати особливе моральне значення прав. Адже така діяльність головна для самоповаги й поваги до інших, саме вона надає сенсу уявленню про особисту гідність [11].

Британський філософ Джон Стюарт Мілль стверджував, що обмеження одного громадянина можна виправдати тільки для того, щоб не завдати шкоди іншим. Таку позицію можна визначити як «принцип не шкоди іншим», або принцип шкоди. Також Джон Стюарт Мілль уважав, що єдина сфера поведінки людини, за яку вона відповідає перед суспільством, - це те, що стосується інших. А у сфері, що стосується лише самої людини, її незалежність, за правом, є абсолютною. Індивід (повнолітній у правовому аспекті) має повне право вільно розпоряджатися собою, своїм власним тілом і розумом.

Фактично свобода дій є у суб'єкта тільки щодо самого себе (винятками є, наприклад, евтаназія або самогубство). Щодо інших свободи дій у суб’єкта немає. У відносинах між суб’єктами є визначений законодавством на даний час перелік прав і обов'язків - визначені межі поведінки, у рамках якої суб'єкт може діяти у правовідносинах, що виникають з іншими суб'єктами. А держава здійснює законотворчу, правоохоронну та посередницьку функції у відносинах, які виникають між суб'єктами.

За законодавством України (ст. 270 ЦК України), право на свободу, яке включає в себе і право на свободу літературної, художньої, наукової і технічної творчості, $€$ особистим немайновим правом особи [2]. ЦК України визначає у ст. 271 зміст особистого немайнового права як можливість фізичної особи вільно та на власний розсуд визначати свою поведінку у сфері свого приватного життя [2]. Отже, право на свободу творчості є правом, яке особа здійснює вільно та на власний розсуд, оскільки здійснення права на свободу творчості стосується насамперед сфери її приватного життя.

Філософ Микола Бердяєв описував свободу як нічим не обумовлену, позитивну творчу міць творити 3 «нічого», яка виходить із внутрішнього світу людини. Уважав, що свобода є детермінованою, тому що сама $є$ причиною. Свобода в позитивному вираженні та твердженні і є творчістю. Таємниця свободи заперечує замкнутість та всілякі кордони. Детермінована тільки еволюція. Саме свобода вносить новизну у творчість [5, с. 138-140].

Також М. Бердяєв поділяв свободу на позитивну - свободу «для», негативну - свободу «від». Негативну свободу (свобода «від») він описував як беззмістовну, пусту, свободу для свободи, без цілі та змісту, усвідомлену суто формально, формальна свобода, тобто свобода «від», а не свобода для творчості. Така свобода перетворюється на необхідність, у ній деградує буття. Філософ пояснював існування у світі формальної свободи тим, що людство на певному етапі проходить випробування 
свободою. Людина на етапі усвідомлення формальної свободи «від» нібито постає перед вибором між абсолютною покорою й абсолютним свавіллям. Наступним етапом є усвідомлення матеріальної, або позитивної, свободи «для», наповненої творчою силою. Свобода «для» - це творча свобода, свобода для продовження творчості, а не бунт у негативному свавіллі [5, с. 141-142].

Пристрасна природа людини не може і не повинна бути зламана, а лише творчо перетворена [5, с. 226]. У процесі життя людина пізнає обрані об'єкти, потім намагається зрозуміти, як систематизувати отриману інформацію: дає визначення, ділить на категорії, види тощо. Але механізм життя та розвитку не стоїть на місці і той звичний поділ із часом може виявитись уже не таким стабільним та єдино істинним. Систематизовані людиною категорії та види можуть поєднуватися та видозмінюватися. Зміни часто сприймаються досить критично, оскільки вони можуть бути небезпечними для вже сформованих і ніби непорушних підвалин. Зміна є наслідком ухвалення нових рішень, проявом свободи, завдяки змінам відбувається розвиток. А. Маслоу зазначав: «Коли вимагаємо досконалого лідера або досконалого суспільства, ми таким чином відмовляємося від вибору між кращим та гіршим. Якщо бачити в недосконалості ваду, то все стає порочним, оскільки досконалості не існує» [4]. Часова послідовність надходження інформації формує структури, які потім повинні бути зруйновані, щоб реорганізувати елементи по-новому. Такий процес може слугувати прийнятною моделлю творчості. Тільки творчій метод дозволяє таким структурам розвиватись [6].

Наявні суперечності у процесі творчості можна схарактеризувати так:

- творець своїм творінням хоче вийти за межі звичного та повсякденного життя [5, с. 232];

- у протилежності творчості та буття постає дилема творіння самого життя або творіння художнього твору;

- у невідповідності між завданням творчого акту та його реалізацією. Завдання є безмежно більшим за реалізацію [5, с. 220];

- відокремлення результату творчої діяльності від автора.

У своєму позитивному вираженні свобода водночас є творчістю та джерелом новизни. Свобода і творчість міцно пов'язані. Свобода є запорукою творчості, без свободи творчість неможлива. Усвідомлення свободи має два рівні: усвідомлення формальної свободи «від» та усвідомлення творчої свободи «для». Автор не може напевне передбачити або контролювати реакцію, яку спричинить його творіння в аудиторії, а також те, на що його твір надихатиме інших у майбутньому. Продукт творчої діяльності в результаті здобуває власну свободу. 3 позиції законодавства можна обгрунтувати це твердження наслідками закінчення строку чинності майнових прав інтелектуальної власності. У ст. 447 ЦК України та ст. ст. 28, 29 Закону «Про авторське право та суміжні права» зазначено, що об'єкт авторського права після спливу строку дії майнових авторських прав переходить у суспільне надбання, що дає можливість вільно використовувати його будь-якою особою [3]. У положеннях ст. 467 ЦК України закріплено, що в результаті припинення чинності виключних майнових прав інтелектуальної власності на винахід, корисну модель, промисловий зразок ці об’єкти можуть вільно та безоплатно вико- 
ристовуватися будь-якою особою [2]. Після закінчення строку дії майнових прав на об'єкт права інтелектуальної власності він може вільно та безоплатно використовуватися будь-якою особою, але таке використання не повинно порушувати особистих немайнових прав інтелектуальної власності.

Важливо підкреслити, що творчість не є сталим явищем. Творчість - це процес якісно нових перетворень та змін явищ, об’єктів, предметів та навіть суб'єктів. Підтвердженням цього є те, що під час творчого процесу автор або творець також зазнає змін, така діяльність, як виховання дітей, коучинг, створення сценічного образу, теж є творчістю, яка впливає на суб'єкта, щодо якого здійснюється творча діяльність.

Творчість може бути дуже різною й іноді досить неоднозначною. Спірні ситуації щодо творчості та порушення прав і свобод, суспільної моралі та цінностей виникають, зокрема, у сфері сучасного мистецтва. Яскравими прикладами таких ситуацій є провокаційні перформанси та фотографічні твори, наприклад, таких сучасних художників, як Ірина Рузіна (серія фотографічних творів «Плодючисть», 2010-2011 рр.), Борис Михайлов (серія фотографічних творів «Історія Хвороби», 1997-1998 рр.), Сергій Братков (серія фотографічних творів «Дітки», 2000 р., перформанс «Хортиця»), Сантьяго Сьєрра (наприклад, перформанс «Лінія в 30 см, витатуйована на людині за винагороду" ("Line Of $30 \mathrm{~cm}$ Tattooed On A Remunerated Person”), 1998 р., Мехіко), Гюнтер Брюс (акція «Прогулянка Віднем», Відень, 1965 р.) та інші.

Способи і форми вираження в мистецтві, як і в будь-якій іншій творчості, бувають різні. Результати творчості можуть породжувати суперечності емоцій, відчуттів та думок. Одним із загальних завдань творчості є дотик у художній формі або через ідейно-емоційний зміст до різних емоцій та думок людини. Тому забезпечення свободи творчості має таке ж велике значення для творців, як і захист прав інтелектуальної власності.

У результаті вивчення творчості можна дійти висновку, що вона відображена в різних підходах, але $є$ загальні ознаки творчості, які можна виокремити, а саме:

- творчість притаманна діяльності людини;

- творчість виникає у процесі діяльності людини або поєднанні різних видів діяльності людини;

- результатом творчості є створені нові якості матеріального та духовного буття;

- творчість грунтується на осмисленні вже наявного досвіду;

- творчість реалізується в суспільстві і є джерелом культурних цінностей суспільства.

Кожна дія людини зумовлена бажанням задовольнити певну свою потребу або інтерес. Особа, коли реалізує право на свободу творчості, також прагне задовольнити свої інтереси, серед них можна виділити такі:

- у пізнанні;

- у зміні / реформуванні / удосконаленні / модернізації;

- потреба донести свою ідею, творчий результат світові;

- бути корисним;

- у визнанні; 
- у самореалізації;

- у матеріальній винагороді.

Ст. 23 Конституції України гарантується право кожного на вільний розвиток своєї особистості, але в межах прав і свобод інших людей, оскільки існують і певні обов'язки перед суспільством, у якому забезпечується повний і всебічний розвиток кожного. У ст. 34 Конституції України гарантується право на свободу думки, слова, вільне вираження своїх переконань і поглядів. А також закріплюється право вільно збирати, зберігати, використовувати і поширювати інформацію усно, письмово або в інший спосіб - на свій вибір. Ст. 54 Конституції України проголошує свободу літературної, художньої, наукової і технічної творчості та захист прав інтелектуальної власності [1].

Цивільний кодекс України забезпечує задоволення інтересів суб'єкта, який здійснює творчу діяльність, шляхом реалізації ним своїх немайнових та майнових суб'єктивних прав. У ст. 11 ЦК України зазначено, що створення літературних, художніх творів, винаходів та інших результатів інтелектуальної, творчої діяльності є підставою для виникнення цивільних прав та обов'язків. У кн. 2 ЦК України визначено право на свободу літературної, художньої, наукової і технічної творчості як особисте немайнове право, що забезпечує соціальне буття фізичної особи. У ст. 270 ЦК України, з посиланням на Конституцію України, зазначено, що фізична особа має право на свободу літературної, художньої, наукової і технічної творчості, таке право є одним із видів особистих немайнових прав. Також у ст. ст. 271 та 272 ЦК України визначено зміст та спосіб здійснення особистих немайнових прав, які схарактеризовані як можливість фізичної особи самостійно, вільно та на власний розсуд визначати свою поведінку у сфері свого приватного життя. Але особливість творчості полягає в тому, що вона прагне вийти за межі навіть свого творця. Це зумовлює деякі суб’єктивні аспекти реалізації права на свободу творчості, які полягають у тому, що спочатку творець для створення результату творчості використовує попередній досвід та матеріальну базу, які були створені іншими. Творчо акумулює та перетворює їх у свій результат інтелектуальної, творчої діяльності та прагне представити своє творіння світові. У цьому також полягають взаємозв'язок і взаємодія творця та суспільства.

На нашу думку, покликання права інтелектуальної власності полягає не тільки в захисті майнових і особистих прав інтелектуальної власності, але і в захисті права на свободу творчості, а також регулюванні відносин, які виникають у зв'язку з реалізацією цього права.

Творчий підхід дозволяе подолати труднощі в умовах різких змін у сучасному суспільному житті, окреслити нову ціль, зумовлену змінами, створити свободу вибору, розкрити свій творчій потенціал кожній особистості [8]. Творчість веде до розвитку особистості, формує зв'язок поколінь та впливає на історичний розвиток [12]. Діяльність людини тільки тоді стає творчістю, коли сприяє розвиткові людської особистості, культури та насамперед духовності особистості. Творчість завжди зумовлена принципами добра, істини, краси та їх синтезом - духовністю [9].

На підставі проведеного дослідження категорії «творчість», їі ознак та сутнісних вимірів уважаємо за необхідне сформулювати такі висновки. 
У своєму позитивному вираженні свобода водночас є творчістю та джерелом новизни. Свобода і творчість перебувають у міцному зв'язку, оскільки свобода є запорукою творчості, а творчість відкриває нові можливості для свободи. Право на свободу творчості є правом, яке особа здійснює вільно та на власний розсуд, оскільки здійснення права на свободу творчості стосується насамперед сфери ї̈ приватного життя. Особливість творчості полягає в тому, що вона прагне вийти за межі навіть свого творця. Автор не може напевне передбачити або контролювати реакцію, яку викличе його творіння в аудиторії, а також те, на що його продукт творчої діяльності надихатиме інших у майбутньому, тому можна сказати, що продукт творчої діяльності в результаті здобуває власну свободу. У правовій площині об'єкт права інтелектуальної власності здобуває власну свободу після закінчення дії майнових прав інтелектуальної власності.

Творчість знаходить своє відображення в різних підходах, але є і загальні ознаки, які можна виокремити: творчість притаманна діяльності людини; творчість виникає у процесі діяльності людини або поєднання різних видів діяльності людини; результатом творчості є створені нові якості матеріального та духовного буття; грунтується на осмисленні вже наявного досвіду; творчість реалізується в суспільстві і є джерелом культурних цінностей суспільства.

Уважаємо, що покликання права інтелектуальної власності полягає не тільки в захисті майнових і особистих прав інтелектуальної власності, але і в захисті права на свободу творчості. А також у регулюванні відносин, які виникають у зв'язку з реалізацією цього права. Творча діяльність є однією зі сфер культурної діяльності. Діяльність у сфері культури є набагато ширшою за творчу діяльність і далеко не завжди має творчий характер.

\section{Jimepamypa}

1. Конституція України : Закон від 1 січня 2020 р. № 254к/96-ВР. Відомості Верховної Ради України. 1996. № 30. Ст. 141.

2. Цивільний Кодекс України : Закон від 16 січня 2003 р. № 435-IV. Відомості Верховної Ради України. 2003. № № 40-44. Ст. 271. № 2694-VIII.

3. Про авторське право та суміжні права : Закон України від 23 грудня 1993 р. № 3792-XII. Відомості Верховної Ради України. 1994. № 13. С. 64. № 2581-VIII.

4. Абрахам М. Мотивация и личность. Пер. с англ. А. Татлыбаева. Санкт-Петербург, 1999. Электронная публикация : Центр гуманитарных технологий, 2011. URL: https://gtmarket.ru/laboratory/ basis/4180 (дата звернення: 29.10.2020).

5. Бердяев М. Смысл творчества : Опыт оправдания человека. Москва, 1916. С. 138-142, 220, $226,232$.

6. Боно Э. Серьезное творческое мышление. Пер. с англ. Д. Онацкая. Минск : 000 «Попурри», 2005. URL: https://psy.wikireading.ru/35056 (дата звернення: 29.10.2020)

7. Бусел В. Великий тлумачний словник сучасної української мови. Київ ; Ірпінь : ВТФ «Перун», 2002. C. 1109.

8. Горбунова К. Формування навичок нестандартного творчого мислення у майбутніх інженерів-педагогів. Проблеми інженерно-педагогічної освіти : збірник наукових праць. УІПА. Харків, 2002. № 3. C. 189-194.

9. Мацко Л., Прищак М. Основи психології та педагогіки : навчальний посібник. Вінниця : ВНТУ, 2009. C. 84 .

10. Нерсесян А. Соціально-правові і філософські основи захисту прав інтелектуальної власності. Часопис Київського університету права. 2009. № 3. С. 167-171. 
11. Фейнберг Д., Коулмен Д. Філософія права. Пер. з англ. П. Таращук. Київ : Видавництво Соломії Павличко «Основи», 2007. С. 365.

12. Цапок В. Творчество : Философский аспект проблемы / отв. ред. Н. Михай ; Молд. гос. ин-т искусств. Кишинев : Штиинца, 1989. С. 148.

\section{Анотація}

Дмитрук А. В. Свобода творчості: поняття, ознаки, сутнісні виміри. - Стаття.

Метою статті є дослідження та соціально-правовий аналіз доктрини та положень законодавства щодо суті поняття свободи творчості, визначення ознак творчості та співвідношення свободи творчості з поняттям культури та суспільної моралі. Для дослідження були використані загальнонаукові і спеціальні методи, що забезпечило виявлення та поєднання аналізу, теоретичних та практичних проблемних аспектів, що виникають у соціальному та правовому розумінні права на свободу творчості. У результаті дослідження були сформовані висновки щодо сутнісних вимірів понять свободи та творчості, виявлені характерні ознаки творчості, охарактеризовано співвідношення свободи творчості, культури та суспільної моралі на законодавчому рівні. Актуальність дослідження також зумовлена тим, що сфера інтелектуальної власності стрімко розвивається. З'являються нові об'єкти права інтелектуальної власності, які потребують визнання та правової охорони. Підтримання інновацій неминуче приводить до прогресу в суспільстві. У багатьох конституціях сучасних держав ідеться про інтелектуальну власність, пов'язану із творчою працею, що знаходить своє відображення в певній сукупності відповідних прав і обов'язків. Ця обставина підкреслює значення свободи творчості, інтелектуальної власності в сучасному світі, актуальність дослідження теми творчості. Оскільки творчість не є сталим явищем, вона стрімко розвивається і на своєму шляху стикається із суперечностями, які потребують вирішення. Творчість знаходить своє відображення в різних підходах, але є загальні ознаки, які були висвітлені у статті. Охарактеризовано співвідношення творчості та культурної діяльності. Окреслені сутнісні виміри права на свободу творчості як особистого немайнового права особи. Визначено, що основою створення будь-якого об’єкта права інтелектуальної власності є культурні надбання попередніх поколінь, але не менш важливі й результати інтелектуальної творчої діяльності, які створюються нині і будуть створюватися в майбутньому. Кількість та різноманітність результатів творчості роблять очевидною потребу вдосконалення законодавства у сферах їх використання.

Ключові слова: свобода, свобода творчості, ознаки творчості, суспільна мораль, право інтелектуальної власності, особисті не майнові та майнові права інтелектуальної власності.

\section{Summary}

Dmytruk A. V. Creative freedom: concepts, signs, essential dimensions. - Article.

The aim of the article is to research and make a socio-legal analysis of the doctrine and provisions of law on the essence of creative freedom concept, to define creative features and correlation between creative freedom and the concept of cultural and public morals. General scientific and special methods of researching were used to ensure identification and combination of analysis, theoretical and practical problematic aspects arose in social and legal understanding of the right to creative freedom. The research enables to make conclusion on the essential dimensions of freedom and creativity, to identify attributes of creativity and to determine a correlation between creative freedom, culture and public morals at the legislative level. The rapid development of intellectual property area determines relevance of the study. New objects of intellectual property rights appear and they need recognition and legal protection. Innovation support imminently leads to society progress. Many constitutions of modern states mention intellectual property associated with creative work which is reflected in a set of relevant rights and responsibilities. This fact emphasizes the importance of creative freedom and intellectual property in the modern world as well as the relevance of creativity research. Since creativity is not a permanent phenomenon, it is developing rapidly and many contradictions arise on the way. All of them need to be resolved. Creativity is reflected in different approaches, but there are common features that have been reviewed in the article. Correlation between creative work and cultural activity are described. The essential dimensions of the right to creative freedom as a personal non-proprietary right are outlined. It is determined that the cultural heritage of previous generations is the basis for the creation of any object of intellectual property rights, but the results of intellectual creativity, which are produced today and will be produced in the future, are important as well. The number and variety of creative results show the need to improve legislation in their sphere of application.

Key words: freedom, creative freedom, signs of creativity, public morals, intellectual property law, personal non-property intellectual rights, personal property intellectual rights. 